\title{
Segregated Intake of Protein-rich and -free Diets in Two Meals a Day; Its Effect on Growth and Vital Functions in Rats
}

\author{
Kaoru Sugryama, Kimikazu Iwami and Fumio IbuKi \\ Laboratory of Food and Nutritional Sciences, \\ Department of Agricultural Chemistry, \\ Kyoto Prefectural University Shimogamo, \\ Sakyo-ku, Kyoto 606, Japan \\ Received June 3, 1991
}

\begin{abstract}
Growing rats meal-fed for 4 weeks with a $20 \%$ or $40 \%$ casein diet in the morning $(9: 00-11: 00)$ and a non-protein diet in the evening $(19: 00-21: 00)$, or vice versa, were examined for growth and metabolic changes. A pair of groups given the $40 \%$ casein diet at one meal and the protein-free diet at the other meal, although becoming a little different from each other in growth, did not significantly differ from the control given only the $\mathbf{2 0 \%}$ casein diet at the two meals. A pair of groups alternately given the $20 \%$ casein and protein-free diets, although excelling in protein efficiency ratio, were far inferior in growth to the groups given the $40 \%$ casein diet at either of the two meals. In any case, the rats with alternation of the diets sufficient and deficient in protein preferred the $20 \%$ or $40 \%$ casein diet to the protein-free one at whichever feeding time, and had a higher body weight gain when the casein diet was administered in the evening. The differences among these groups in protein intake throughout the experimental period were roughly reflected in their growth curves. A similar tendency was also observed for the blood urea level and hepatic serine dehydratase activity. As to the individual free amino acids in the plasma, however, there was no significant difference between the control and other groups except for a few amino acids (Ser, Gly and Phe).
\end{abstract}

Prolonged protein deficiency doesn't only depress the growth of animals but also, which is worse, impairs vital functions even though there is no lack of other nutrients. For this reason, a proper protein supplementation is necessary for the maintenance of sound vital activity. Taking into consideration normal eating habits, separation or conformity between the protein and calorie intakes at meals has been a matter of concern in the field of nutritional sciences from long ago. ${ }^{1-5)}$ There were some conflicting observations in this connection. For example, Cuthbertson et al. ${ }^{87}$ have described how the mechanism in growing rats is unaffected by protein intake at separate times from the other food constituents, while Geiger ${ }^{7)}$ has referred to a growth lag due to the delayed protein supplementation under pair-feeding conditions. Animals can, however, adapt to unbalanced feeding, by which they can bear up under a short-term protein deficiency. The pool amino acids regardless of the origin from protein turnover or intraluminal protein digestion, would be preferentially used for the restoration of renewal of functional proteins in the body systems. ${ }^{8)}$ It is probable that the restriction on protein intake scales down the amino acid pool size and thereby regulates the rate of protein synthesis and/or degradation. Conversely it may be said that the protein preservation of animals with alternation of the protein-rich and-free diets is more raised than usual at least to such an extent as to compensate for a loss by resupply of the protein after its intermittent depletion. We have set up work on the efficacy of unbalanced feeding from the viewpoint of a physiological stress rather than a nitrogen saving, and have found that young rats alternately given the protein-free and 20\% casein diets every second, third, or fourth day grow similarly to those continuously given the $10 \%$ casein diet (unpublished).

In this investigation, it was examined to what 
extent growing rats adapt to alternate feeding with the protein-free and -rich diets at two meals, in the morning and evening.

\section{Materials and Methods}

Animal experiment. Male albino Wistar rats weighing about $50 \mathrm{~g}$ (Shimidzu Experimental Animals Co., Kyoto) were individually housed in wire-bottomed cages in an air-conditioned room with a 12 hour light/dark cycle (lights-on, 7:00-19:00) and allowed free access to a 20\% casein diet for a week. Then the animals were divided into 5 groups, followed by meal-feeding with semi-purified experimental diets (in a blended powder state) according to the feeding-time schedule of twice a day shown in Table I. At the end of 4 weeks, the rats were fasted overnight and killed by carotid amputation to collect the blood as well as to excise the liver. The plasma was separated from the red blood cells by centrifugation and kept frozen until use. The liver was weighed and homogenized with 4 volumes of a saline solution in a Teflon-glass homogenizer. The supernatant following centrifugation at $1000 \times g$ for $10 \mathrm{~min}$ was assayed for protein and glutathione.

Hepatic DNA, protein, and glutathione determinations. The liver, which had been kept frozen, was thawed just before use and homogenized with 4 volumes of cold saline solution. DNA was separated as described by Schmidt et $a .^{9)}$ and measured by the diphenylamine method. ${ }^{103}$ Protein was measured by the method of Lowry et al. ${ }^{11}$ ) Giutathione in the homogenate was measured on the basis of the absorbance measurement at $412 \mathrm{~nm}$ after its treatment at $\mathrm{pH} 6.8$ with $5.5^{\prime}$-dithiobis(2-nitrobenzoic acid) as described by Jocelyn. ${ }^{12}$

Hepatic enzyme assays. The liver homogenate was centrifuged at $105,000 \times g$ for $60 \mathrm{~min}$, and the resulting supernatant was used for the assay of enzymes such as arginase and serine dehydratase. For the arginase assay, a 20- $\mu$ l sample of the enzyme solution was incubated at $37^{\circ} \mathrm{C}$ and $\mathrm{pH} 9.7$ for $10 \mathrm{~min}$ together with $1 \mathrm{ml}$ of the substrate solution consisting of $7.5 \mathrm{~mm}$ L-arginine and $0.5 \mathrm{mM} \mathrm{MnSO}_{4}$, and the reaction was stopped by adding $2.5 \mathrm{ml}$ of $10 \% \mathrm{TCA}$. After centrifugation at $1,000 \times \mathrm{g}$ for $10 \mathrm{~min}$, the urea content in the supernatant was measured by the diacetylmonoxime method. ${ }^{13)}$ For the activity measurement of serine dehydratase, a 100- $\mu$ l sample of the enzyme solution was added to $0.9 \mathrm{ml}$ of the assay medium at $\mathrm{pH} 8$ containing $100 \mu \mathrm{mol}$ of potassium phosphate, $0.05 \mu \mathrm{mol}$ of pyridoxal phosphate, and $1 \mu \mathrm{mol}$ of EDTA, followed by incubation at $37^{\circ} \mathrm{C}$ for $5 \mathrm{~min}$. The reaction was stopped by adding $0.5 \mathrm{ml}$ of $10 \% \mathrm{TCA}$, and after removal of the denatured proteins, $0.5 \mathrm{ml}$ of $0.033 \%$ 2,4-diphenylhydrazine in $2 \mathrm{~N} \mathrm{HCl}$ was added to trap pyruvate as its hydrazone, which was measured by absorbance measurement at $500 \mathrm{~nm}$ subsequent to the addition of $2 \mathrm{~N} \mathrm{NaOH} .{ }^{14)}$ The activity of both enzymes was expressed as $\mu \mathrm{mol} / \mathrm{mg}$ DNA of product (urea or pyruvate) formed permin under the respective assay conditions.

Measurements of various biochemical parameters in the plasma. The total protein and albumin concentrations in the plasma were measured by the biuret method ${ }^{157}$ and the dye-binding capacity with bromocresol green, ${ }^{18)}$ respectively. The globulin concentration was calculated from the difference between the two. The plasma urea was measured in the same manner as used for the arginase assay. The free fatty acid was measured colorimetrically using cupric nitrate and 1,5-diphenylcarbazide. ${ }^{17)}$ The glucose and triacylglycerol were routinely measured using commercially available assay kits (Wako Pure Chemical Industries, Ltd., Osaka). For the purpose of amino acid analysis, the plasma was pretreated with an equal volume of $10 \%$ TCA. The denatured proteins and excess TCA were removed by repeated centrifugation at a high speed and extraction with ethylether. The clarified aqueous layer, after being once freeze-dried, was dissolved in the buffer and was part put on the column in an automated Kyowa K-202 amino acid analyzer (Kyowa Seimitsu Co., Tokyo).

Other chemicals of analytical grade were commercially obtained and used without further purification.

Statistical analysis. Data were expressed as means $\pm \mathrm{SE}$ for 8-10 animals. It was evaluated by the StudentNewman-Keuls test ${ }^{19}$, whether or not the differences among means are significant as to the groups with significant $F$-value $(<0.05)$.

\section{Results}

Figure 1 depicts the growth curves of rats with alternation of the diets at both meals in the morning and evening on the feeding schedule shown in Table I. Their body weights tended to decrease until they get accustomed to meal-feeding, but began to increase a few or several days after the start of the experiment. As a whole during all the experiment period, differences were observed among the groups in weight gain. When group A given the $20 \%$ casein diet at the two meals in the morning and evening was taken as a control, groups B and $\mathrm{C}$ alternately given the $20 \%$ casein and non-protein diets were far inferior to the control in growth, between which there seemed a difference in growth depending on what time the protein was supplied. Although groups D and $\mathrm{E}$, alternately given the $40 \%$ casein and 


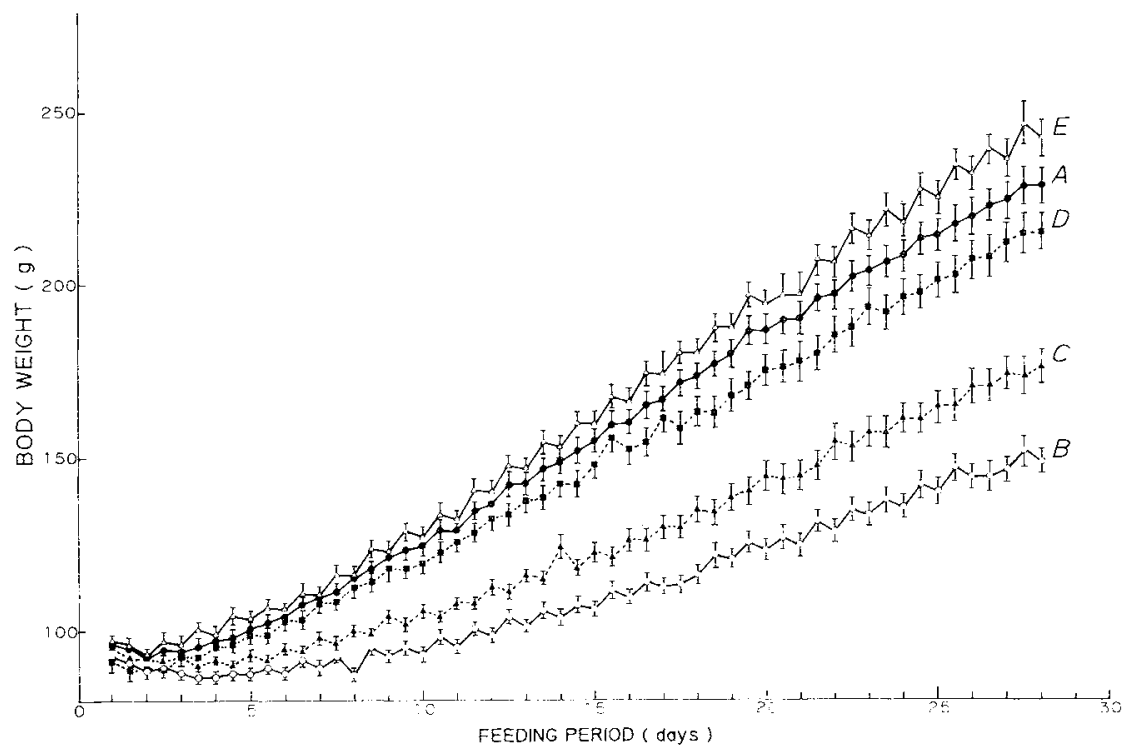

Fig. 1. Growth Curves of Rats Alternately Given Protein-rich and -free Diets on Meal-feeding Schedule over a Period of 4 Weeks.

The conditions for the meal-feeding schedule are shown in Table I. Symbols and bars represent the means $\pm \mathrm{SE}$ for 8-10 animals.

Table I. Time Schedule for Meal-Feeding and Composition of Diets

\begin{tabular}{|c|c|c|}
\hline \multirow{2}{*}{$\begin{array}{c}\text { Group } \\
(n=8 \cdots 10)\end{array}$} & \multicolumn{2}{|c|}{ Diet supplied at } \\
\hline & $9: 0011: 00$ & $19: 00-21: 00$ \\
\hline A & $20 \%$ Casein & $20 \%$ Casein \\
\hline$B$ & $20 \%$ Casein & Protein-free \\
\hline $\mathrm{C}$ & Protein-free & $20 \%$ Casein \\
\hline $\mathrm{D}$ & $40 \%$ Casein & Protein-frec \\
\hline $\mathrm{E}$ & Protein-free & $40 \%$ Casein \\
\hline
\end{tabular}

The rats were fed by meal-feeding and allowed free access to drinking water all the time.

protein-free diets, were not significantly different from the control in growth, the rats of group E given the high-protein diet in the evening seemed to grow better than those of group D given it in the morning. Table II summarizes the average daily amounts of food and protein intakes per $100 \mathrm{~g}$ of body weight and the respective protein efficiency ratios (PER's) throughout the feeding period of 4 weeks. The food intakes at the stated times twice a day were separately totalled from a physiological point of view. In practice, the amount of food intake at AM 9:00-11:00

\begin{tabular}{lc}
\hline \multicolumn{1}{c}{ Ingredient } & $\begin{array}{c}\text { Composition } \\
(\%)\end{array}$ \\
\hline Casein & $(0,20,40)$ \\
x-Corn starch & $(85,65,45)$ \\
Oil mixture & 5 \\
Mineral mixture & 5 \\
Vitamin mixture & 1 \\
Cellulose powder & 4 \\
\hline
\end{tabular}

All of the ingredients were products of Oriental Yeast Co.

differed from that at PM 19:00-21:00 in case of group $\mathrm{A}$ receiving the same diet. On the contrary, the $20 \%$ or $40 \%$ casein diet was preferable to the protein-free diet irrespective of the feeding-times in the other groups than A. On making a comparison among the groups about their protein intake, the amount of its consumption was found to be in order of $\mathrm{E}>\mathrm{A} \geqq \mathrm{D}>\mathrm{C} \geqq \mathrm{B}$, which had been reflected in their body weight gain. In contrast to this order, PER tended to decrease with increasing amounts of protein intake, except for the inversion of $B$ and $C$. The PER values in 
Table II. Food and Protein Intakes and Protein Efficiency Ratio in Rats Meal-fed for 4 Weeks as SCheduled

\begin{tabular}{|c|c|c|c|c|}
\hline \multirow{2}{*}{$\underset{(n)}{\text { Group }}$} & \multicolumn{2}{|c|}{ Food intake (g/100g of BW) } & \multirow{2}{*}{$\begin{array}{c}\text { Protein intake } \\
\text { (g/day } / 100 \mathrm{~g} \text { of } \mathrm{BW})\end{array}$} & \multirow{2}{*}{$\begin{array}{l}\text { Protein } \\
\text { efficiency } \\
\text { ratio }\end{array}$} \\
\hline & $9: 00-11: 00$ & $19: 00-21: 00$ & & \\
\hline$A(9)$ & $4.47 \pm 0.08^{a}$ & $5.18 \pm 0.09^{\mathrm{a}}$ & $1.93 \pm 0.03^{a}$ & $1.73 \pm 0.05^{a}$ \\
\hline $\mathrm{B}(8)$ & $5.16 \pm 0.15^{b}$ & $4.22 \pm 0.12^{b}$ & $1.03 \pm 0.03^{b}$ & $1.92 \pm 0.08^{b}$ \\
\hline C (10) & $3.65 \pm 0.12^{c}$ & $6.10 \pm 0.22^{\mathrm{a}}$ & $1.22 \pm 0.05^{b}$ & $2.12 \pm 0.05^{\mathrm{c}}$ \\
\hline$D(9)$ & $5.41 \pm 0.33^{b}$ & $4.56 \pm 0.12^{b}$ & $1.82 \pm 0.13^{\mathrm{a}}$ & $1.41 \pm 0.04^{\mathrm{d}}$ \\
\hline$E(9)$ & $4.15 \pm 0.13^{\mathrm{ac}}$ & $5.88 \pm 0.12^{\mathrm{a}}$ & $2.35 \pm 0.05^{\circ}$ & $1.86 \pm 0.04^{\mathrm{ab}}$ \\
\hline
\end{tabular}

The dietary conditions for groups A-E are shown in Table I lleft $)$. The differences between means without a common superscript in the same column are significant $\left(\alpha_{T}<0.05\right)$ as a result of the Student-Newman-Keuls test.

Table III. Hepatic Levels of Protein, Glutathione, and Enzyme Activity in Rats MEAL-FED FOR 4 WEEKS AS SCHEDULED

\begin{tabular}{|c|c|c|c|c|c|}
\hline \multirow{2}{*}{$\begin{array}{c}\text { Group } \\
(n)\end{array}$} & \multirow{2}{*}{$\begin{array}{l}\text { Liver weight } \\
(\mathrm{g} / 100 \mathrm{~g} \text { of } \mathrm{BW})\end{array}$} & \multirow{2}{*}{$\begin{array}{c}\text { Protein } \\
\text { (mg/g of liver) }\end{array}$} & \multirow{2}{*}{$\begin{array}{c}\text { Glutathione } \\
(\mu \mathrm{mol} / \mathrm{g} \text { of liver) }\end{array}$} & \multicolumn{2}{|c|}{ Activity, unit/mg DNA } \\
\hline & & & & Arginase & Serine dehydratase \\
\hline$A(9)$ & $3.25 \pm 0.06^{\mathrm{a}}$ & $239 \pm 6$ & $2.70 \pm 0.18^{\mathrm{a}}$ & $220 \pm 8^{\mathrm{ac}}$ & $5.78+0.79^{a}$ \\
\hline$B(8)$ & $2.91 \pm 0.07^{b}$ & $233 \pm 6$ & $1.58 \pm 0.08^{b}$ & $162 \pm 8^{b d}$ & $1.63 \pm 0.10^{\mathrm{b}}$ \\
\hline $\mathrm{C}(10)$ & $3.14 \pm 0.05^{a}$ & $254 \pm 15$ & $2.25 \pm 0.11^{\mathrm{c}}$ & $193 \pm 11^{\text {ad }}$ & $1.58 \pm 0.25^{\mathrm{b}}$ \\
\hline $\mathrm{D}(9)$ & $3.61 \pm 0.06^{\mathrm{c}}$ & $257 \pm 9$ & $1.93 \pm 0.12^{\mathrm{bc}}$ & $245 \pm 16^{\mathrm{c}}$ & $5.61 \pm 1.08^{\mathrm{a}}$ \\
\hline$E(9)$ & $3.72 \pm 0.08^{\circ}$ & $242 \pm 10$ & $3.90 \pm 0.16^{\mathrm{d}}$ & $213 \pm 11^{\mathrm{ac}}$ & $7.25 \pm 0.29^{\mathrm{a}}$ \\
\hline
\end{tabular}

The same animals as in Table II were used for these assays. The means \pm SE $(n=8-10)$ not sharing a common superscript in the same column are significantly different at $\alpha_{\mathrm{T}}<0.05$.

groups $\mathrm{C}$ and $\mathrm{D}$ corresponding to the highest and lowest, respectively, were significantly different from that in the control.

The effect of dietary exchange in mealfeeding was examined on the protein and glutathione contents in the liver as well as the arginase and serine dehydratase activities there (Table III). The liver weight was higher in both groups D and $E$ that had received the $40 \%$ casein diet at either of the feeding times than in the control, whereas it was lower in group $B$ (but not in group C) that had received the $20 \%$ casein diet at the stated time in the evening. The hepatic protein level tended to be a little high in groups $\mathrm{C}$ and $\mathrm{D}$, although not singificantly. Significant differences were observed among the groups with respect to the hepatic glutathione as a major reservoir of cysteine, which varied appreciably according to the dietary component previous to death, reflecting the nutritional situation of the sulfur amino acids. Ingestion of the $40 \%$ casein diet previous to death was more effective in the glutathione accumulation in the liver than that of the $20 \%$ casein diet, to say nothing of the protein-free diet. Arginase and serine dehydratase among a number of enzymes responsible for amino acid metabolism were known to change adaptively in their hepatic level upon continuous feeding with a very high-protein diet. Such was not necessarily the case with alternate ingestion of the $40 \%$ casein and protein-free diets. These enzyme activities were rather lowered by alternation of the proteinfree and $20 \%$ casein diets.

As an aid for assessment of the proteinnutritional status, the rats of each group having the time-limited access to the diets were examined for changes of some biochemical parameters in the plasma (Table IV). The total protein and albumin contents in the plasma were found higher in group $\mathrm{E}$ given the $40 \%$ casein diet a half-day before death than in the other groups including the control $\mathrm{A}$. The ratio 
Table IV. Plasma Protein, Urea, Glucose, and Fat Levels in Rats Meal-fed for 4 Weeks as Scheduled

\begin{tabular}{lccccc} 
Plasma parameter & $\mathrm{A}$ & $\mathrm{B}$ & $\mathrm{C}$ & $\mathrm{D}$ & $\mathrm{E}$ \\
& $(9)$ & $(8)$ & $(10)$ & $(9)$ & $(9)$ \\
\hline Total protein, $\mathrm{mg} / \mathrm{dl}$ & $4.49 \pm 0.20^{\mathrm{a}}$ & $4.28 \pm 0.12^{\mathrm{a}}$ & $4.20 \pm 0.13^{\mathrm{a}}$ & $4.12 \pm 0.21^{\mathrm{a}}$ & $5.21 \pm 0.11^{\mathrm{b}}$ \\
Albumin, mg/dl & $2.49 \pm 0.16^{\mathrm{a}}$ & $2.49 \pm 0.10^{\mathrm{a}}$ & $2.41 \pm 0.14^{\mathrm{a}}$ & $2.53 \pm 0.07^{\mathrm{a}}$ & $3.19 \pm 0.07^{\mathrm{b}}$ \\
Albumin/globulin ratio & $1.19 \pm 0.09^{\mathrm{a}}$ & $1.29 \pm 0.13^{\mathrm{ab}}$ & $1.48 \pm 0.12^{\mathrm{ab}}$ & $1.65 \pm 0.10^{\mathrm{b}}$ & $1.61 \pm 0.10^{\mathrm{b}}$ \\
Urea, $\mathrm{mg}-\mathrm{N} / \mathrm{dl}$ & $5.02 \pm 0.25^{\mathrm{a}}$ & $2.30 \pm 0.21^{\mathrm{b}}$ & $2.95 \pm 0.27^{\mathrm{b}}$ & $4.65 \pm 0.33^{\mathrm{a}}$ & $10.00 \pm 0.65^{\mathrm{c}}$ \\
Glucose, $\mathrm{mg} / \mathrm{dl}$ & $114.1 \pm 3.4^{\mathrm{a}}$ & $107.5 \pm 3.2^{\mathrm{a}}$ & $91.2 \pm 3.2^{\mathrm{b}}$ & $112.1 \pm 4.7^{\mathrm{a}}$ & $116.2 \pm 3.7^{\mathrm{a}}$ \\
Triacylglycerol, $\mathrm{mg} / \mathrm{dl}$ & $91.9 \pm 13.1^{\mathrm{a}}$ & $51.5 \pm 3.2^{\mathrm{b}}$ & $68.3 \pm 6.5^{\mathrm{b}}$ & $68.3 \pm 6.8^{\mathrm{ab}}$ & $78.4 \pm 7.3^{\mathrm{ab}}$ \\
Free fatty acids, $\mu \mathrm{M}$ & $998 \pm 62$ & $967 \pm 76$ & $877 \pm 49$ & $776 \pm 50$ & $815 \pm 40$
\end{tabular}

The animals used for these assays were the same as those in Tables II and III. The results of measurements of several biochemical parameters in the plasma were arranged sideways. There is a significant difference at $\boldsymbol{x}_{\mathrm{T}}<0.05$ between the means $\pm \mathrm{SE}(n=8-10)$ without a common superscript in the same range.

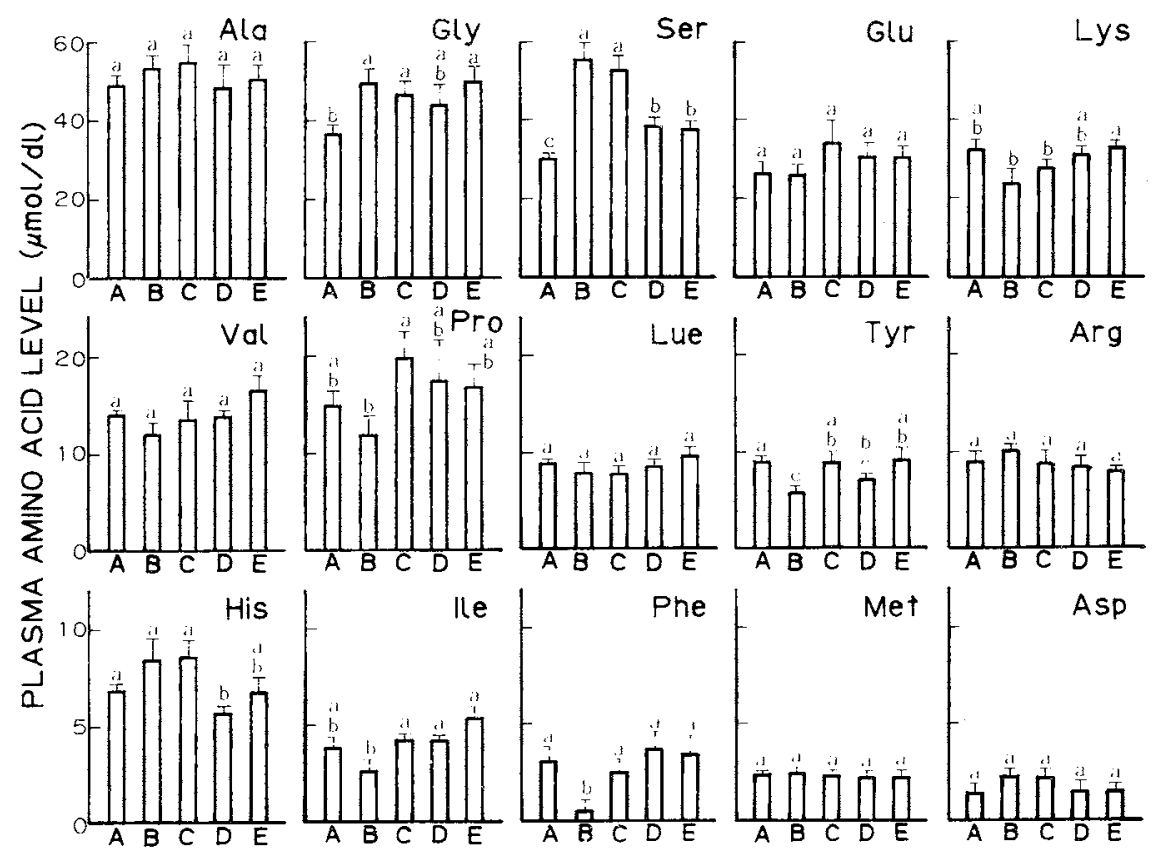

Fig. 2. Plasma Levels of Free Amino Acids in Rats Fed for 4 Weeks as Scheduled.

The animals are the same as those used in Tables II-IV. The means \pm SE $(n=8-10)$ not sharing a common superscript in the individual amino acids are significantly different at $a_{\mathrm{T}}<0.05$.

of albumin to globulin was as much in group $\mathrm{D}$ as in group $\mathrm{E}$, which was higher in both groups than in the control. The plasma urea concentration was likewise high in group $\mathrm{E}$ and low in groups $\mathrm{B}$ and $\mathrm{C}$ when compared with that in the control. Ingestion of the highprotein diet previous to death left a trail of elevation of these parameters relating to the protein or amino acid metabolism. On the contrary, the plasma glucose level was kept almost constant irrespective of the kinds of experimental diets given at the feeding times, except for a somewhat low level in group $\mathrm{C}$ given the $20 \%$ casein diet previous to death. The plasma triacylglycerol level seemed to be lower in the other groups than in the control, but only group B poor in growth was significant among them, because of the existence of a relatively large standard error in the control. Similarly, the free fatty acid concentration in 
the plasma had a tendency to be lessened by ingestion of the protein-free diet at either of the feeding times.

Groups D and E, although a little different from each other in growth, were regarded as in a similar protein-nutritional status when compared with the control. Such a situation had been virtually reflected in the plasma levels of branched, aromatic and other essential amino acids; that is, there was no significant difference among the three groups in any amino acids (Fig. 2). In group B, worst in growth and given the protein-free diet previous to death, there was a tendency to decrease in the plasma isoleucine and phenylalanine levels and to increase in that of serine. It is possible that a shortage of protein was caused by separate meal-feeding with the protein-free and $20 \%$ casein diets, especially when the former diet was administered at the time for lights-out (i.e., before the rats, nocturnal in their habits, go into action).

\section{Discussion}

Alternate-day ingestion of the $40 \%$ casein and protein-free diets was in close proximity to continuous ingestion of the $10 \%$ casein diet rather than that of the $20 \%$ casein diet in view of the growth over a period of feeding (unpublished results). In contrast to this, segregated intake of these diets at two meals of $2 \mathrm{~h}$ twice a day was almost equal in the rat growth to repeated intake of the $20 \%$ casein diet (Fig. 1). On the early days after the start of meal-feeding, the rats were so bewildered as not to ingest food enough for the growth within the prescribed feeding-time. The amount of food intake in those days was reduced by half relative to ad libitum feeding (data not shown). A week later, the animals accustomed themselves to the time restriction and began to put on weight. The rate of increase in weight in these "meal-fed" rats, which was obtained as approximately $5.5 \mathrm{~g} /$ day from the slope of a linear part in the growth curve, seemed a little worse than that in the "reference" rats freely given the diet with the same composition (approximately $6 \mathrm{~g} /$ day in another experiment). The cumulative food intake after then in the former (meal-fed rats) didn't go up to over $90 \%$ of that in the latter (ad libitum fed rats), because there was a limit to the amount of food that could be swallowed at a meal. Taking into account actual eating habits, however, it isn't good for health to eat too much. In this connection, there is an interesting report ${ }^{19)}$ that the life-span of mice is much prolonged by a proper restriction of food intake. Daringly speaking, unbalanced protein feeding at a meal doesn't necessarily go against nourishment, as long as the nutrition balance is held day by day.

It is generally accepted that the food intake is modulated by hormone release from the gut, ${ }^{20,21)}$ probably playing a part in the peripheral satiety system as well. One of the most prominent candidates for appetite regulation is cholecystokinin (CCK), for which the evidence is mounting, ${ }^{22-24)}$ while its antagonists provoke the appetite. ${ }^{25)}$ Evidence is increasing for supporting the idea that $\mathrm{CCK}$ plays a physiological role not only in the regulation of food intake but also in the enhanced memory retention associated with feeding. ${ }^{26)}$ Additionally it is known that dietary protein provides a stimulus to CCK secretion from the small intestinal mucosa, thereby raising pancreatic exocytosis. ${ }^{27)}$ Such a functional rise is accounted for by a negative feedback control mechanism in which dieary protein temporarily masks active proteases in the lumen. The higher the protein content in the diet and its consumption are, the more the CCK discharge into the blood may increase. Accordingly, ingestion of a very high-protein diet ought to bring about satiety more quickly than usual. In practice, the rats in a low-nutritive situation tended to avoid such a high-protein diet. Another explanation is that the animals cannot adapt enough in amino acid metabolism as to eat a large amount of the high-protein diet. ${ }^{28,29)}$ Incidentally, the casein diets used in this experiment were not so excessive in protein that the meal-fed rats would have been averse to eating it.

The rats with alternation of the $20 \%$ or $40 \%$ 
casein and protein-free diets showed a preference for the casein diet at whichever feeding time, in the morning or evening, it was served. Such a preference for protein to starch had been already pointed out in the diet-choice experiment. ${ }^{30,31)}$ Similarly, the rats to which the $20 \%$ casein diet was administered by meal-feeding twice a day, ate more in the evening than in the morning. The evening meal is compared to breakfast in human eating habits. It is reasonable from the viewpoint of two meals a day that much more food is ingested before going into action. In case of alternate administration of the diets abundant and poor in protein, not only the former diet was preferable to the latter one but also consumption of the former was larger at the feeding-time zone in the evening. A difference in protein intake between the groups ( $\mathrm{B}$ and C) given the $20 \%$ casein diet at either of the two feeding-times was reflected in their body weight gain throughout the experimental period. A similar relation held for the groups (D and E) given the $40 \%$ casein diet at either of the two feeding-times.

It was also a matter of primary concern in this study whether or not the segregated protein intake shows a sign of excessive or scanty protein even temporarily. The view that the $40 \%$ casein diet is not so high in protein as to exceed the metabolic capacity, was actually confirmed by comparison of the hepatic enzyme activity (Table III) and free amino acid levels in the plasma (Fig. 2) with those in the control, although the effect of high-protein feeding previous to death was impressed on the plasma total protein, albumin, and urea levels and the hepatic glutathione level to some extent. As a consequence of the foregoing, it can be safely said that alternation of the protein-rich and -free diets at separate feeding-times is virtually of the same nutritive value as repetition of their average protein diet at all meals, if the meal-feeding is justified as actuality. Of course, it remains to be investigated how much a long-term repetition of protein-sufficient and-deficient diets affects vital functions.

\section{References}

1) R. A. Harte, J. J. Travers and P. Sarich, J. Nutr., 35, 287 (1948).

2) E. Geiger, Science, 108, 42 (1949).

3) H. N. Munro, J. Nuir., 39, 375 (1949).

4) D. J. Becker, Ann. Rev. Nutr., 3, 187 (1983).

5) J. C. Waterlow, Am. Rev. Nutr., 6, 495 (1986).

6) D. P. Cuthbertson, A. McCutchenon and H. N. Munro, Biochem. J., 34, 1002 (1940)

7) E. Geiger, J. Nutr., 36, 813 (1948).

8) A. E. Harper, Can. J. Biochem., 43, 1589 (1965).

9) W. C. Schneider, J. Biol. Chem., 164, 747 (1946).

10) K. Burton, Biochem. J., 62, 315 (1956).

11) O. H. Lowry, N. J. Rosebrough, A. L. Farr and R. J. Randall, J. Biol. Chem., 193, 265 (1951).

12) P. C. Jocelyn, Biochem. J., 85, 480 (1962).

13) J. J. Coulombe and L. A. Favreu, Clin. Chim., 9, 102 (1963).

14) M. Suda and H. Nakagawa, Methods Enzymol, 17B, $346(1970)$

15) A. G. Gornall, C. J. Bardawill and M. M. David, $J$. Biol. Chem., 177, 751 (1946).

16) B. T. Doumas, W. A. Watson and H. G. Biggs, Clin. Chim. Acta, 31, 87 (1971).

17) K. Falholt, B. Lund and W. Falholt, Clin. Chim. Acta, 46, 105 (1973)

18) S. A. Grantz, "Primer of Biostatistics," 2nd Ed., MacGraw-Hill Inc., New York, 1987, pp. 91-95.

19) R. H. Weindruck and R. L. Walford, Science, 215 , 1415 (1982).

20) S. R. Overman, Phychol. Bull., 83, 218 (1976).

21) J. C. Peters, D. J. Nemetz, J. K. Tews and A. E. Harper, Nutr. Rep. Int., 27, 407 (1983).

22) H. R. Kissileff and T. B. Van Itallie, Ann. Rev. Nutr., 2. 371 (1982).

23) C. G. Nicholl, J. M. Polak and S. R. Bloom, Ann. Rev. Nutr., 5, 213 (1985).

24) G. P. Smith, C. Jerome, B. J. Cushin, R. Eterno and K. J. Simansky, Science, 213, 1036 (1981).

25) H. R. Kissileff, F. X. Pi-Sunyer, J. Thornton and G. P. Smith, Am. J. Clin. Nutr., 34, 154 (1981).

26) G. Stacher, H. Steinringer, G. Schmierer, C. Schneider and S. Winklehner, Peptides, 3, 133 (1982).

27) A. J. Silver, J. F. Flood and J. E. Morley, Peptides, 9, 221 (1988).

28) J. F. Flood, G. E. Smith and J. E. Morley, Science, 236, 832 (1987)

29) T. Corring, C. Juste and E. F. Lhoste, Nutr. Res. Rev., 2, 161 (1989)

30) W. E. Knox and O. Greengard, Adv. Enzyme Regul., 3, 247 (1965).

31) Y-S. Peng, L. L. Meliza, M. G. Vavich and A. R. Kemmerer, J. Nutr., 104, 1008 (1974). 